\title{
READING FICTION FOR BETTER LIFE IN LUIS SEPULVEDA'S THE OLD MAN WHO READ LOVE STORIES
}

\author{
Melania Priska Mendrofa \\ Sekolah Tinggi Bahasa Asing Prayoga Padang, Indonesia. \\ melania@stba-prayoga.ac.id
}

\begin{abstract}
Reading is therapeutic. This statement reflects reading as a way of healing mental problems and increasing self-ability. Researches prove that reading is not only for entertainment but also a tool to solve a problem in people's life. Meanwhile, the question comes up in the term of what kind of book suggested to read. This research applied qualitative method. In Luis Sepulveda's novel entitled The Old Man Who Read Love Stories, it is implied that reading fiction helps the old man, Antonio, to deal with his old age and loneliness. Reading a love story enlightens the old man's mind and feelings. Life is overloaded by complex problems, such as war, poverty, gender problem, and nature destruction. People become sentimental to life; there is no happy ending story in life, only death. Meanwhile, Sepulveda sees fiction as the rescuer for a problematic life. This paper discussed why people read fiction and the effects of reading fiction on someone's life. The positive impacts of reading fiction on mental health and self-transformation are supposed to encourage people to start a new habit of reading for a better life.
\end{abstract}

Keywords: reading, fiction, mental health, self-transformation

\begin{abstract}
ABSTRAK
Membaca merupakan sebuah terapi. Pernyataan ini mencerminkan bahwa membaca adalah sebuah cara menyembuhkan masalah mental dan meningkatkan kemampuan diri. Peneliti membuktikan bahwa membaca tidak hanya untuk hiburan, tapi juga merupakan alat untuk memecahkan masalah dalam hidup. Namun, pertanyaan muncul tentang buku apa yang seharusnya dibaca. Penelitian ini menggunakan metode kualitatif. Dalam novel Luis Sepulveda yang berjudul Pak Tua yang Membaca Kisah Cinta, disiratkan bahwa membaca karya fiksi telah membantu seorang pak tua bernama Antonio untuk berdamai dengan masa tua dan kesendiriannya. Membaca karya fiksi, dalam hal ini berupa cerita cinta, telah mencerahkan pikiran dan perasaan si pak tua. Kehidupan telah dibebani dengan masalah rumit, seperti perang, kemiskinan, masalah gender dan perusakan alam. Orang-orang menjadi sentimental akan hidup; beranggapan bahwa tidak ada akhir hidup yang bahagia, yang ada hanya kesedihan. Namun, Sepulveda melihat karya fiksi sebagai sebuah penyelamat untuk hidup yang penuh masalah. Artikel ini akan membahas alasan mengapa orang membaca karya fiksi, serta pengaruh yang ditimbulkannya dalam hidup. Pengaruh positif yang ditimbulkan dari membaca karya fiksi terhadap kesehatan mental dan perubahan diri diharapkan mampu mendorong orang-orang untuk memulai kebiasaan baru dalam membaca untuk hidup yang lebih baik.
\end{abstract}

Kata kunci: membaca, fiksi, kesehatan mental, perubahan diri 


\section{INTRODUCTION}

To read is to heal. This sentence means so much since studies find reading can heal people's health. It is literature that is believed to increase well-being and mental health (Billington, 2019). The activation of the imaginative realm from reading fiction helps people to deal with stress and to distance themselves from a daily issue in life. It even allows people to re-describe their life through imagination (Billington, 2019). From the statement, reading starts to get a high position as the self-healing method. Reading can reduce the risk of trauma, and let the reader has some comfort spaces in their mind, and re-create a self-peaceful world.

The importance of reading also derives from the text allowance to the creativity of the readers. The texts evoke readers' minds to be active in responding to the story. They are supposed to be both a receptive reader and reflective critic (Colclough, 2007). It implies how reading forces people to keep thinking, imagining, and questioning something new in their life. The new information and idea from a literary text can encourage people to construct a new horizon of life. Fiction provides new knowledge, understanding, and sharpens ethical sense (Zunshine, 2006).

Concerning the importance of reading, not all literary texts help the healing of mental health. A newspaper, for instance, is not a good choice for those who want to relieve stress. The actual news of war, politics, the economic crisis even creates more stress for readers. To anticipate stress, people tend to choose fiction as an alternative reading. Reading fiction has more positive impacts on readers. The readers can have better emotions and perceptions toward life since fiction offers stories closely experienced by the readers. Readers can get imaginative realms of power, in which they can imagine themselves to be the hero or heroine in the story (Isabel \& Buchenau, 2004). By characterizing themselves a hero, it can reduce their stress and sadness. Furthermore, reading also improves people's empathy toward other people (Tamir et al., 2015). It is implied in this novel that Sepulveda proposes a positive change in the affective domain of fiction reading through Antonio's character.

This study aims to elucidate the significance and effect of reading fiction for life. The significance of fiction represents the sense of why people read fiction through the perspective of the theory of mind. It exposes reading activity as a way to trigger the reader's emotion. After finding the justification of reading activity, there are also reading effects found for the readers. This study then submits the mental health effect and self-transformation as a result of fiction reading. After all, it proposes an understanding of the crucial function of fiction in enlightening people's minds and souls.

\section{LITERATURE REVIEW}

\section{Theory of mind}

Before coming to the impact of reading fiction for life, we should 
acknowledge the sense of why people read fiction. Although fiction is imaginative writing, it supports readers with life information and knowledge. There are so many topics that correlate to human's dilemma, such as love, war, prosperity, gender issues, and so on. Through the characterization of a hero, heroine, and villain, the reader can find and learn a new situation they never dealt with. The information from this fiction can be used to improve real-world beliefs (Ooi \& Liew, 2011). This view reminds us that the essence of reading fiction is not only for enjoyment purposes, but also to help the readers gain new insight, knowledge, belief, and idea.

To get a deep insight into why people read fiction, this study engages the analysis by using a theory of mind. When reading fiction, the reader is allowed to drown themselves in the atmosphere of the story. According to research, brain networks become active when processing stories (Berns et al., 2013). This research implies how fiction reading supports the imagination and thinking process. The reader can feel the situation encountered by the character. A reader may have the ability to explain someone's behaviour, such as their thoughts, beliefs, feeling, and desires (Zunshine, 2006). This activity, which is well known as mind-reading, assists the reader to take issue with certain circumstances presented in a story.

Close to the reader's ability to engaging with the characters' lives, the novel also has a role in constructing people's interest to read. A novel with aesthetic value can determine personal liking toward the book he may read. Everyday life information sources, however, affect the reader's choice of fiction book (Ooi \& Liew, 2011). It is to argue that a reader pursues the gap in his knowledge and feeling through fiction reading. The reader can get new information from reading fiction. new In this study, the analysis of Antonio's character represents the search for the older person's greatest need in life, for purpose in life (Romani, 1973). Thus Antonio's enjoyment in fiction reading for the searching of a peaceful mind is in line with the implementation of everyday life information seeking (ELIS) proposed by Ooi and Liew (2011).

Furthermore, reading fiction encourages the emotional bonding between the characters and the reader. This emotion, as clarified by Zunshine (2006), can trigger another cognition. When a reader feels good emotional pleasure through a story in a novel, then it can create his or her enjoyment toward the novel. The reader can experience emotions in reading fictional literature (Mar \& Oatley, 2008). It points out the correlation of fiction reading with the recovery of mind-health also. This function of enjoyment to someone's health is also proposed by Haworth (2016) who stated that older people who enjoy life showing declines in physical function. Haworth reminds us that enjoying life is crucial to avoid the development of health problems, particularly in old age. Emotional pleasure built during reading fiction indirectly assists the reader to explore and express their hidden feeling.

Thus, with a brief analysis of why fiction reading is important for people, this study argues that Sepulveda undertakes the main function of fiction to shape people's interest in new knowledge and information, and to improve the well-being. 


\section{Reading fiction for mental health and self-transformation}

Billington (2019) proposed reading as a mentalization-based theory to show reading as the therapy which can help people to understand their feeling and others. Some mental problems are represented in someone's inability to establish a relationship with their mind, and also a relation with others. To solve this problem, one can use reading as a therapy to self. It is to say that reading becomes an answer to recreational satisfaction (Alejo et al., 2013). It gives us a perspective that a person uses reading as media to heal their burden; it can reduce depression and anxiety.

About the mental-healing process, narratives in imaginative literature help the reader to identify and explore their experience, the past, and the present. Billington (2019) noted that the coherent story of experience can be therapeutic. The readers can express their personal experiences through reading imaginative literature. Imaginative literature also allows the reader to release daily pressure in this modern era (Usherwood \& Toyne, 2002). It challenges the function of fiction reading that helps the reader to expose their implicit pain through the reading novel and to relax their mind. Besides that, fictional works can re-describe reality (Gleeson, 1992). By reading similar characters' life and experience with their own, the readers are involved in it. The readers can recognize the repeated experienced memories from a story. Thus by reading and involving in the story, it evokes negotiation and tolerance toward the readers' repressed memory. It is worth pointing out that the reader can recognize and release their burden through the recognition of the characters' feelings.

Furthermore, reading is believed to affect the changing view of self, the world, and others. Smaragdi \& Jonsson (as cited in Alejo et al,. 2013) noted that for self, reading can increase the ability of logical reasoning, the ability to express oneself, comprehension, and understanding (p. 93-94). This argument underlines the point of reader self-improvement. Besides, fiction reading also gives access to selftransformation which allows the reader to have a better personality. Reading fiction evokes direct reference. Direct reference is explained as the attentional gesture oriented toward the bodily present (Billington, 2019). It correlates to the sense of the same, in which reading literature may recall the same past experiences of the readers. There is conscious acceptance from the readers toward their repressed memory and burden after reading fiction. It offers a view that the narratives accompany the readers to encounter their loneliness. It changes the view of self from being alone and the depressed one into the 'normal' or 'one of many' because some people also experience the same burden as them (Billington, 2019). From the justification, fiction reading hits the viewpoint of self-transformation as the improvement in affective domain made up by reading.

Overall, the studies above show the significance of recognizing the importance of fiction reading. The narratives help the reader to develop both their cognitive (knowledge, information, belief, and idea) and affective (mental health and self-transformation). 


\section{RESEARCH METHOD}

This research applies qualitative methods to explore and to explain a social phenomenon, to construct understanding about some aspects of life (Leavy, 2014). The analysis brings forward the discussion of a social problem, which is the importance of reading fiction for life. The data used in this study is a novel by Luis Sepulveda entitles The Old Man Who Read Love Stories. This novel was originally written by a Chilean writer, Luis Sepulveda, published in 1989, and won three major literary awards. It narrates the struggle of an old man who encountered the destruction of the natural world by Western civilizations. Therefore, the writer found another interesting aspect to analyze from Antonio's character, which is his hobby for reading novels. After his wife's death, Antonio spends his day alone in his small hut and becomes a member of Shuar's tribe. He enjoys his loneliness by reading some novels that he got from the neighborhood library. His favorite fiction is about suffering love theme because it reminds him of his personal life of losing a beloved wife, Dolores. Reading fiction helps Antonio to revisit his memory. The similar story between the novel and his life reminds him that nothing is everlasting. The suffering love of the hero and heroines helps him to realize that he is not the only person who suffers from losing a beloved person. The fiction reading finally heals his mental suffering and transforms his life to be a sympathetic person.

The discussion creates critical thinking which aims to question Antonio's tendency to read fiction and the effects of it on his life. To strengthen the process of critical thinking, the writer applies a sociological approach. Saukko (2003) mentions that the function of the social approach is to clarify the empowering and disempowering aspects of discourses both from personal as well as social points of view. Concerned to this point, the writer explored the social roots and implications of the discourses that intertwine people's real life. This exploration helps the writer analyze the social phenomenon; which is the importance of reading fiction for life. The writer goes through some steps in analyzing the topic. First, the writer reads the novel and finds the problem within the story. Second, the writer sets the background and impacts of the problem. Third, there are interpretations of the problem and organization of the research question. The entire steps guide the writer to specify theories used in the analysis, which are the theory of mind and reading for mental health.

Both theories are applied for the research since it concerns two main aspects; the relation between mind and reading, and the impact of reading on life. The discussion of mind and reading underlies the concept of mind-reading as the basic understanding of human activity in reading. Further, reading for mental health describes the effects of reading fiction for someone's mental health and selftransformation. Thus this research method does not only aim to question why people read fiction but also overcomes the effects of it on the readers' health and personality. 


\section{FINDING AND DISCUSSION}

In general, this novel presents the situation of Western civilization and human relations with nature. Therefore, there is one interesting area to be discussed through Antonio's character. This novel presents a unique character, an old man who likes reading a love story in his old age and loneliness. Luis Sepulveda tries to show the reader how reading does not limit the reader's level of age. The special thing about the old man is his extraordinary desire for reading a suffering love story, and how it then brings a self-transformation. This study attempts to look at Antonio's portrait and examine the reason why someone read fiction and its effects on life.

\section{a. Antonio's interest in reading fiction}

The narration shows Antonio's passion for reading, especially for a love story. He prefers to read the love story because it shows the struggle of the characters to find their true love. Florence Barclay's El Rosario is one of his favorite stories because it tells about the suffering characters that struggle for love and live in misery as well. The mournful narration makes him cry a lot until his loop getting wet (Sepulveda, 2017). Antonio has no interest in a perfect love story, where the characters seem to have no problem in their life. He likes a sad love story. He enjoys 'suffer' with the characters. By reading Edmundo D'Amicis and Corazon, Antonio concludes that no one can suffer so badly, or be afflicted endlessly (Sepulveda, 2017).

Luis Sepulveda narrates Antonio as a reading maniac. When Antonio exposes his reading ability, he always becomes 'hungry' for reading. When loneliness comes after him, he just needs to read (Sepulveda, 2017). In his place, El Idilio, he finds no book. He finally goes to the neighborhood, El Dorado. There, he meets a headmistress who allows him to read books in the school library. Antonio drowns himself in pages of books. In 5 months, he improves his reading skill and taste. $\mathrm{He}$ questions himself and tries to find the answer from the book.

Nevertheless, Antonio sorts out some books from his reading list. While reading a geometry book, he questions whether reading is useful or not. Some terms found in the book sounds ridiculous. Hypotenuse, for instance, is the only formulation mastered by Antonio. When he mentions the word to his people, they think his tongue is twisted. The term sounds like a mantra for them (Sepulveda, 2017).

Not only the geometry book, but Antonio also doubts the historical book. In his mind, it is a fictive book. He is suspicious of the child's story who can win the war. He wonders how the innocent and pale child can gain victory in war. They are just a child who is even scared to kill flies (Sepulveda, 2017). Political issues make Antonio bored as well. Once, El Idilio's Mayor allowed him to read some old newspaper. The issues seem irrelevant to his life experience. The news covers the speech of a Congress member who insults the other members, a murder case whose suspect claims to have no motives in killing his friend, and chaos in a football match. 
The cases are boring for Antonio. He has no idea about congress and football matches. It is out of his life circle. He spends his life living in a jungle with El Idilio's people. Nature is his home. For him, the news cannot make him living in his imagination (Sepulveda, 2017). He does not recognize the real world. He wants to grow an imaginative world in his head; a story that makes him feel alive.

From Antonio's case, it can be seen clearly that he chooses fiction over nonfiction one. Reading fiction pleasures him. Fiction has the capacity to re-describe reality. It brings language into a pre-objective world; a world where someone is rooted (Gleeson, 1992). Antonio is described as a character who has a longing for love. His interest in fiction reflects his lost desire for love. Antonio has a sad love story. His wife, Dolores, dies because of malaria in their second year of marriage. His loss affects his mind in which he becomes more sensitive to sorrowfulness. $\mathrm{He}$ becomes sentimental when he reads a sad love story. Emotion gives meaning to our minds (Zunshine, 2006). By reading fiction, it helps Antonio deal with his emotion. The character in fiction makes him realize that he is not alone. As he assumed before that no one can bear sorrowfulness in his life. Life is not only about a feeling of sorrow, but also happiness. Reading fiction helps him to create a new form of meaning for his everyday existence (Zunshine, 2006).

Antonio's sad experience in love has turned into a meaningful episode in his life. This is reflected in the picture of his wife which is still hanging up in his small house. Dolores has been forever in his mind, where the loneliness has rooted in silence (Sepulveda, 2017). In his old age, Antonio feels lonely. That is a love story's book that amuses him during his heavy time in memorizing his deceased wife. It brings back all memories they ever had, and Antonio may realize that sorrow is a part of a human's life story. The fiction has its aesthetic beauty in symbolizing morality (Gleeson, 1992). Knowing the moral truth of a story will help Antonio to know the new realm of reality, where love does not always end in a happy moment. The world also serves sadness to make people realize their feeling of longing for love.

Tension in a love story is also crucial in fiction to ensure the occurred recognition (Gleeson, 1992). Antonio never complaints about the truth of the love story. For him, fiction is more realistic than the newspaper. Fiction allows the reader to feel the real world atmosphere through the existence of tragedy. The novels read by Antonio mostly destroy the life of the heroine or the hero through their death. It gives tension between the fiction and the real. It will allow Antonio to see the actual life even in a fictive story. Antonio gets the complete feeling from reading fiction and love story. He can feel the love nuance and moral truth as well.

\section{b. The effect of reading fiction on Antonio's life}

From Antonio's case, Luis Sepulveda emphasizes the dominance of fiction in helping people to find a better life. Science and technology are indeed significant in life development. Therefore, humanities should come first, so people know how to cooperate in creating, applying, and developing science and technology in life 
(Billington, 2019). The theme of humanities is mostly exposed in fiction, such as human relations, identity, compassion, injustice, love, family values, equality, freedom, and many others. Through fiction, readers are guided to have empathy in life, and also enable social understanding. Antonio's hobby of reading sentimental novels helps him healing his mental health, and constructing a new perspective toward life.

\section{Reading fiction for mental health}

It is explained before that reading has a good impact on life, and so does fiction. There is the influence of fiction toward someones' mental health. Firstly, it helps with the growth of the readers' imagination. Antonio spends his time reading novels, pondering the secret of love, and imagining where the stories took place (Sepulveda, 2017). He reads many new places, such as Paris, London, Geneva, Prague, and Barcelona. He tries hard to imagine those cities. Comparing to Ibarra, the only big city he ever visited, those new places attract his attention. He also likes a snowy place. There is always an imaginative correlation between every place he reads to his past life with his wife, Dolores. Loja and Zamora are two places he ever passed by with Dolores once, and he compares those places to Prague and Barcelona. He assumes that love may not arise in those small places. Only in the new places he never visited before, love may grow well. This thinking helps him to grow his desire for love. His repressed feeling of love and memories of some places help him to get happiness. The re-visited memories finally help Antonio to heal his sadness.

The growth of imagination also provides freedom for Antonio. Since he has lived alone, the only entertainment activity he has is the book. Living in a jungle and staying far from others make Antonio choose the book as his 'window' for life. He gets different freedom, where he should not move around or spend money and time to visit a new place. The novel allows him to free his imagination, to build a new world as he wishes for. A reader can be a traveller for the story he reads (Colclough, 2007). Fiction gives authorization for the readers to use text for their purpose. Even though Antonio has no idea on how the new place looks like, thus his imagination can help him to 'see' it.

Since fiction allows the reader to use text as their purpose, Antonio can freely choose how he situates the hero, heroine, and villain in the novel. When he reads a story of Paul and Gondola in Venetia, for instance, he has so many imaginative opinions on Paul's character. The opening paragraph of the novel is described as follow:

"Paul is kissing the woman passionately while his friend,
the Gondolier, pretends to look to another side. The full
cushioned Gondola then slowly moves along the
Venetian's canal" (Sepulveda, 2017, p. 65).

The story triggers Antonio's mind to investigate Paul's characteristics. He 
thinks Paul is a pervert person since he kisses the woman passionately in front of his friend, the Gondolier. He can describe the figure with any type of person he likes. Therefore, Paul may not be the kind of bad figure in the novel, there is no need to find the truth of it, or involve an intentional object. Antonio has no loss for the meaning of the story. Compare to the scientific book and actual news he ever read, it will be problematic if he makes the wrong description of the real person and condition. Thus the freedom assigned by fiction is to reduce the mental burden of the reader and provides an exciting moment in constructing the delightful life of the characters.

The freedom in fiction also assists Antonio to get away from boredom. Once again, Antonio has a longing for love. He needs to revisit his love feeling. Before moving to El Idilio, he lives with Shuar's people. It is narrated that Antonio does not need a love story when he lives with Shuar's people (Sepulveda, 2017). He falls in love with nature and Shuar's way of life. Therefore, in El Idilio, the situation is different. There is no love, and Antonio has to live alone in a small hut. This new life seems to force him to find a new activity to get away from boredom. A love story's novel is the best solution for him. He gets his longing for love through the story and has the activity to play with his imagination in 'drawing' the narration. It is to say that reading keeps people from being lonely (Kokkevi et al., as cited in Kourkouta et al., 2018, p. 2).

After all, fiction is really helpful for mental health. There will be an inner emotional feeling that can be released after reading a love story. The more someone understands his or her emotion, the more it is in their power (Billington, 2019). Antonio has strong emotional power, thus reading love stories helps him to explore and 'explode' the feeling. It is fiction that can release the hidden feeling and give his spirit for life back.

\section{Reading fiction for self-transformation}

When fiction helps to heal the mental health of the reader, it gives a further impact on the readers' personality as well. The pleasure he finds in reading love stories pushes him to be a better man. He can see the world from a different perspective. A love story has significant meaning, in which it concerns what something means to the reader or others (Gleeson, 1992). The reader may reflect the meaning of fiction through his behaviour or speech. When a love story triggers Antonio's longing for love, this feeling grows his spirit to live life well. It will affect someone's behaviour.

In Antonio's case, the acceptance of significant meaning can be seen from the transition of understanding the story to his desire of living the new life as narrated in the story. He enjoys his life in his small hut without being disturbed by the loneliness. Lately, he reads a romantic novel that tells the story of a romantic couple from Italia. Wondering every action done by the characters helps Antonio to have a peaceful mind. He turns himself into a calm person. While living with Shuar, he becomes tough to himself. Hunting, planting, and doing anything to keep survive are 
his daily activity. He almost finds no spare time for himself. Everything he does is to fulfill his desire. He makes physical activity as a way to hide his sadness. Thus by reading fiction, he finally finds his new self. He is no longer a devoted person. He can appreciate his emotional wound by realizing that no one can escape from misery. He turns himself into an easy-going person.

Antonio's self-changing from a devoted person to be an easy-going person reflects the creation of fiction in changing someone's sense as a normal person. Living with Shuar has changed Antonio's life in many ways. He becomes closer to nature, knows how to survive in nature, and loves nature so much. Meanwhile, there is a thing he cannot experience with Shuar but exist in the love story. The passionate kiss of the characters reminds him of his wife. Shuar's people never kiss (Sepulveda, 2017). He ever saw resistance from a Shuar's girl who was kissed by a gold miner in the jungle. The love story allows him to re-visit his kissing memory with his wife. They rarely kiss each other because of Dolores' old thought that kissing may be a sin. The passionate kissing in the novel read by Antonio represents the normal action people do in life. He is not the sinner. He is one of many. It against his thinking that a kiss is a sin or forbidden action for people. Fiction enables Antonio to challenge his previous idea and thinking of being different from Shuar's people.

Another self-changing encountered by Antonio is his ability to engage with others' ideas. In his expedition to find a beast with El Idilio's people, he gets a chance to share the novel with them. The three men have an interest in the story but had no idea of some new words they hear from Antonio. Antonio describes the words, such as Gondola, the gondolier, and passionate kiss with his speculation. The other men also deliver their explanations of the story. For them, the place in the novel is a kind of weird place. They imagine the situation in Venetia; a rainy place, flooded area, and uncanny surrounding to pee. They have so much fun in engaging their idea of fiction.

Moreover, engaging with others' ideas helps them to improve their perspective and knowledge. When Antonio and the men are involved in a small discussion about Venetia, the Mayor comes up with his knowledge of the place. He informs them that Venetia is a floating city in Italia. This new information triggers many questions from the men they question the function of the boat since the people can go everywhere with their rafted-house. The Mayor adds an explanation that the houses have a stone foundation under the water to hold their position. Meanwhile, those men have already known about the floating stone, which cannot be used to build a floating house. They argue the Mayor's explanation by assuming the impossibility to use floating stone as a foundation. They provide a new idea that people may use some boards under the water to keep the foundation. The argument and different ideas allow them to be critical thinking people. Since fiction is not merely a fictive narration, it also helps the reader to get knowledge and truth of a situation and condition. Antonio and other men can get knowledge of how Venetia looks like from the Mayor's story. Thus fiction brings transformation of knowledge for the readers. 
The more people read, they will have better empathy and understanding of others (Billington, 2019). This can be found through Antonio's action toward the Black Panther. He has a mission from the Mayor to collect the bone of a white man who has been killed by the panther. However, Antonio finally finds the reason behind the panther's attack. The female panther protects her male who has been shot by the white man. After reading love stories, he can understand that love is everything. The female panther is angry with the white man, and she wants to take revenge. When seeing the dying male panther, Antonio cannot help himself to free him from the pain. He finally kills the male panther not because he wants to protect himself, but for mercy. He feels the female's suffering in seeing her dying partner. After shooting the wounded male panther, he cannot see the female panther, but he wonders her hiding and sobbing somewhere (Sepulveda, 2017). Through reading fiction, Antonio understands that no one in this world can live without sorrow (Sepulveda, 2017). He has had the saddest feeling of watching his wife's pain, and he feels it too in the female panther. Instead of seeing both of the panthers suffer, death is the only way to end the pain.

At the end of the novel, Antonio's sympathy can also be seen through his deep regret for killing the female panther. To save himself from the female's attack, Antonio pulls the trigger and kills her. $\mathrm{He}$ is so lamentable. Ignoring the pain in his leg, he strokes the panther and sobs with embarrassment. He feels useless and being a loser for the fight (Sepulveda, 2017). This situation reflects Antonio's deep sympathy for the killed panther. He even blames himself for being such a loser. His eyes fill with tears, and he washes away the panther's body into the river. He sends her into the deep forest where there are no white men around (Sepulveda, 2017). Antonio's struggle to take care of the dead female panther shows his sympathy to the panther which has been killed by white men. He does not leave the dead body there. $\mathrm{He}$ shows his last respect to the female panther by sending her away from the white men. Finally, it is narrated that Antonio goes back into his hut and enjoys reading books that narrate love in a lovely way. He just wants to leave human cruelty behind, and leave in peace.

\section{CONCLUSION}

Reading fiction is not merely about being an imaginative person and living in an unreal world. Sepulveda presents the function of fiction reading to show the reader's relation with fiction, both in the cognitive and affective domain. People read fiction to get knowledge, information, belief, and idea. Antonio gets new knowledge of some new places he never visited before. Besides that, fiction allows the reader to have an emotional bond through the narration of the character. In the affective domain, reading fiction can heal mental health because it can release the inner emotional feeling and wash away the boredom. Self-transformation is also another result of reading fiction. It allows the reader to have a new perspective on something. By knowing and understanding something from a new perspective, we can be more sympathetic to our surroundings. 


\section{BIBLIOGRAPHY}

Alejo, Bilyson D., Balnao, Connie Lou G., \& Aquino, Luisa B. (2013). Fiction Reading on Head and Heart. International Journal of English and Literature (IJEL), 3(1), 89-98. http://www.tjprc.org/publishpapers/--135961749315.English\%20-\%20IJEL\%20-\%20Fiction\%20Reading\%20.full.pdf

Berns, Gregory S., Blaine, Kristina ., Prietula, Michael J., \& Pye, Brandon E. (2013). Short- and Long-Term Effects of a Novel on Connectivity in the Brain. Brain Connectivity, 3(6), 590-600. DOI: 10.1089/brain.2013.0166

Billington, Jose. (Ed.). (2019). Reading and Mental Health. Switzerland: Palgrave Macmillan. https://doi.org/10.1007/978-3-030-21762-4

Colclough, Stephen. (2007). Consuming Texts: Readers and Reading Communities, 1695-1870. NY: Palgrave Macmillan.

Gleeson, Gerald P. (1992). The Value of Reading Fiction. The Sydney Society of Literature and Aesthetics Journal, 2, 6780.https://openjournals.library.sydney.edu.au/index.php/LA/article/view/535 $6 / 6050$

Haworth, J. (2016) Enjoyment and Wellbeing. CWiPP Working Paper No.6, Centre for Wellbeing in Public Policy, University of Sheffield. www.Sheffield.ac.uk/cwipp/working-paper

Isabel, Ana., \& Buchenau, Aliaga. (2004). The "Dangerous” Potential Of Reading: Readers and the Negotiation of Power in Nineteenth-Century Narratives. NY \& London: Routledge.

Kourkouta, L., Iliadis, C, Frantzana, A, \& Vakalopoulou, V. (2018). Reading and Health Benefits. $J$ Healthc Commun, 3(4:39), 1-4. https://www.researchgate.net/publication/329601541_Reading_and_Health_ Benefits

Leavy, Patricia. (Ed.). (2014). The Oxford Handbook of Qualitative Research. NY: Oxford University Press.

Mar, R. A. and Oatley, K. (2008). The function of fiction is the abstraction and simulation of social experience. Perspectives on Psychological Science, 3(3), 173-192. http://lchc.ucsd.edu/MCA/Mail/xmcamail.2009_12.dir/pdfJEO79Qqyg3.pdf

Ooi, Kamy., \& Liew, Chern Li. (2011). Selecting fiction as part of everyday life information seeking. Journal of Documentation, 67 (5), 748-772. https://www.researchgate.net/publication/254187488.

Romani, Dorothy. Reading Interests and Needs of Older People. (1973). Library Trends, 21(3), 390-403. http://hdl.handle.net/2142/6690 
Saukko, Paula. (2003). Doing Research in Cultural Studies: An introduction to classical and new methodological approaches. London: SAGE Publications.

Sepulveda, Luis. (2017). Pak Tua yang Membaca Kisah Cinta (2 ${ }^{\text {nd }}$ ed.). Terjemahan oleh: Ronny Agustinus. Tangerang Selatan: Marjin Kiri.

Tamir, Diana I., Bricker, Andrew B., Dodell-Feder, David., \& Mitchell, Jason P. (2015). Reading fiction and reading minds: the role of simulation in the default network. Social Cognitive and Affective Neuroscience, 1-10. doi:10.1093/scan/nsv114

Usherwood, Bob., \& Toyne, Jackie. (2002) The Value and Impact of Reading Imaginative Literature. Journal of librarianship and Information Science, $34(1)$, 33-41. http://citeseerx.ist.psu.edu/viewdoc/download?doi=10.1.1.854.4622\&rep=rep $1 \&$ type $=$ pdf

Zunshine, Lisa. (2006). Why We Read Fiction: Theory of Mind and The Novel. Columbus: The Ohio State University Press. 